\title{
FORGING A NEW TYPE OF FEMINIST IDENTITY: CHICANA FEMINISM, FEMININITY, AND THE INSTITUTION OF MEMORY
}

Monica GOT ${ }^{1}$

\begin{abstract}
Drawing on Jan Assmann's interpretation of cultural memory as devoid of any racial/biological component, as well as James Clifford's repudiation of the notion of cultural purity, the paper redefines memory as a mentally configured cultural institution, claiming that any reconfiguration of group identity is an act of symbolic violence. By emphasizing the crucial role that identity plays in understanding the fundamental themes tackled by Chicana literature - patriarchal oppression, racial terror, domestic abuse, sexism, homophobia -, the paper illustrates the extent to which the ethnic-gender binomial, i.e. belonging to a group that faces bias on various levels (femininity, Mexican American genealogy and, sporadically, sexual minority status), stands at the very core of the desire to redefine identity that largely fuels contemporary Chicana prose.
\end{abstract}

Keywords: cultural memory, collective identity, Chicana literature, symbolic violence, trauma.

DOI: $10.24818 / \mathrm{SYN} / 2021 / 17 / 1.01$

\section{Introduction}

Since memory is not just an individual, personal experience, but also part of the collective domain, it must primarily be defined as a phenomenon in direct relation to the present. Perception (either group or individual) of the past, being perpetually influenced by the experience of the present, finds itself in a constant and inevitable process of change. Jan Assmann, the promoter of the concept of cultural memory, advocates in favor of a firm rejection of the numerous attempts to formulate collective memory in biological terms, as transmissible memory or racial memory ${ }^{2}$. According to Assmann, it should rather be interpreted as a merely indicative cultural framework, central to the process of identifying how different cultural groups and communities translate their own experiences and write their own stories.

\footnotetext{
${ }^{1}$ Monica Got, Bucharest University of Economic Studies, monica.got@rei.ase.ro

${ }^{2}$ Proposing the concept of "cultural memory," Assmann recommends that we "free ourselves from the reductionism that would like to limit the phenomenon of memory entirely to the body ... and the idea of a deep structure of the soul that can be passed down biologically. Our memory has a cultural basis and not just a social one" (Assmann, 2006: 8).
} 
The present research focuses on resituating Chicana literature within the contemporary Western canon, underlining the importance of memory as a cultural institution and the culture of memory as a symptom of modernity, in an intensely multicultural and transnational world. Starting from the premise that trauma plays an essential role in the formation of Chicana identity - both on an ethnocultural and sociological level, as well as a literary manifestation-, the article attempts to reconceptualize the notion of collective/cultural trauma by following the evolution of certain Chicana literary characters who, despite the constant victimization process to which they are subjected by a patriarchal, androcentric, misogynistic and racist society, manage to break the cycle of abuse by transforming their own traumatic experience into a process of empowerment (emancipation and identity transformation in accordance with their own rules).

Building on Jan Assmann's definition of cultural memory, which rejects the idea that there is a racial, biological component to collective memory, the article redefines memory as a cultural institution (memory as a symbolic space, configured on a mental level), conceptualizing the reconfiguration of group identity as an act of symbolic violence. Since, according to the historian James Clifford, the notion of national or cultural purity is utterly nonsensical, what this study considers is the fluidity and permeability exhibited by the identity of diasporic communities, with great emphasis on the bilingual and hybrid character of migration literature (from both a formal and thematic point of view).

The rather rigid and restrictive - although somewhat justifiable etymologicallymeaning of the term institution places this concept in the concrete, firmly ordained, and pre-classified. Any institution is defined as a space whose location is exclusively designed according to the specific purpose a given place is assigned: a reality which also applies to cultural institutions. On the other hand, by abolishing any adherence to reality, the tangible and thus limitative side of the notion of institution fades away, the latter becoming a strongly symbolic space, a mental space, a space of imagination - which results in a considerable expansion of the representations that formerly matched the traditional idea of institution (be it national, religious, cultural or otherwise).

Therefore, the cultural institution can be seen as a symbolic space, configured at a mental level, populated by characters equally symbolic, who mobilize their energies in order to highlight their main mission. Since culture has its own shades of identity, both spatial and temporal, in order to reconstruct the Bakhtinian chronotope one must examine the various subsystems that make up the very concept of culture. Hence, history - or whatever occurs in a cultural context — is itself a cultural construct: at the core, we are all products of the semiotic space that we inhabit, and cultural institutions have a historical incidence. 
Given that modernity is a set of symbolic shocks administered to the old idées reçues, the modern spirit itself is based on a certain amount of symbolic violence. The mental map configured by the exponents of modernity is based on an analeptic vision of history, while historical consciousness, the evolutionary understanding of the literary text or its referential nature are all elements that define modernity in relation to the perception of time and the evolution of collective memory as a cultural institution. In this regard, it was James Clifford who fought the idea that "pure" nations or cultures really exist, drawing attention to the painful need that those "specific dynamics of dwelling/traveling"-routes, possible ways forward, in relation to the roots, to origins (routes/roots) - be analyzed from a comparative point of view. Only this way does it become possible for the Bakhtinian chronotope of culture to end up being "as much a site of travel encounters as of residence" (Bakhtin and Holquist, 1981: 24-25).

Varied definitions of the notions of exile, migration or diaspora were thus called into question and described as fluid, permeable, mobile - including virtually all attitudes and discourses that had previously been deemed contradictory. Cosmopolitanism, now no longer perceived as a dimension only accessible to a privileged minority (namely expatriate artists, intellectual elites or eccentric travelers), is redefined in order to also include migration phenomena. All these references to the concepts of root/origin and nation led, among others, to a noticeable position of transplantation, creating the revolutionary concepts of "rooted cosmopolitanism" (Appiah, 2005: 98) and "cosmopolitan patriot" (Appiah, 2005: 91) .

Another driving factor of globalization is provided by the new opportunities for global interaction, which have radically changed the way in which migrants participate in their communities - be they local, national or transnational — and the manner in which they intend to preserve their own cultural roots or develop innovative forms of expression in literature.

\section{2. (Re)Defining a Few Central Aspects of Chicana Identity}

Although English has acquired the status of lingua franca, in the United States' recent history monolingualism has faced various challenges, with Spanish becoming an official language in several states. The United States' assimilation policy-a frequent practice that reduces all languages to a single common denominator-has encountered violent opposition from Chicana writers, who have crossed cultural and linguistic borders, vocally demanding the use of hybridization in literature. The fluidity of identity, resistance to assimilation, bilingualism, and hybridity have

\footnotetext{
3 "The cosmopolitan patriot can entertain the possibility of a world in which everyone is a rooted cosmopolitan, attached to a home of his or her own, with its own cultural particularities, but taking pleasure from the presence of other, different, places that are home to other, different, people" (Appiah, 2005: 91).
} 
become increasingly conspicuous features of the migration literature currently produced by women writers of North America.

As a manifestation of individuals acting in a compactly organized societal context, literature plays a key role in the formation and preservation of cultural identity. Since the (more or less traumatic) sociohistorical context in which a group develops its identity cannot be ignored, the so-called culture of memory (whose ultimate focus is the public awareness of history) is gaining more and more ground in modernity. In the case of the Chicana/o community, some forms of national historical consciousness are more visible than others, and literature is merely the natural filter through which collective representations of the past manage to come to light. Looking at history from a postcolonial point of view, Chicana/o literature forces a reconceptualization of the very mental construct called 'history' and automatically pushes towards a redefinition of memory's pre-established points of reference. Fiction, as the supreme outlet of collective thought, turns into an alternate history of a community faded-both culturally and identity-wise.

Grasping the essence of Chicana identity calls for a thorough analysis of such notions as assimilation, hybridization, and the so-called mestizaje (interbreeding) of different cultures, traditions, and ways of life. It is quite clear that the reality known to Chicanas is significantly different from that experienced by the men in their community, as well as that of other more privileged female groups, especially Anglo women. Chicanas are subjects to trifold discrimination: firstly as women, secondly as members of a heavily discriminated ethnocultural group, and thirdly because of the strong patriarchal idiosyncrasies of their own community, which rejects lesbianism as a rebellion against the 'natural' order of things. Their own Chicana identity puts Chicanas at a great risk of experiencing trauma, as individuals facing a very standalone type of reality, whose circumstances are different from those of all other disadvantaged groups. However, what they still have in common with the rest (Chicano males and white feminists alike) are a few defining aspects that characterize them both as members of the Chicana community and as women whose claims have a strong feminist core.

Chicanas are women who, as Chicana writer and activist Gloria Anzaldúa theorizes, represent female duality symbolized by the ambivalent goddess Coatlicue (the Aztec 'Mother of Gods'), women able to absorb and transform all the elements which make up their identity: "Simultaneously, depending on the person, she represents: duality in life, a synthesis of duality, and a third perspective-something more than mere duality or a synthesis of duality" (Anzaldúa, 1987: 46).

A vibrant echo of such dual nature can be easily identified in the notion of border and its transgression and/or acceptance, an element which becomes instrumental in the future of Chicana reality. This idea of border highlights the ambivalent and inclusive character of these women's reality, as individuals who live their lives inside 
the very boundaries of belonging and difference, respectively, with respect to the numerous groups that surround them.

Their existence revolves around the sense of community they share with various members of their group, at the same time depending on the need to establish themselves as different, according to their unique feminine Chicana identity and the characteristics of each individual forming this community. Thereby, the Chicana is recognized as an entity both complex and altogether different, with this spirit of difference being celebrated and reinforced by each and every member of the group. Indeed, the Chicana community has proven open and receptive to the diversity of all outside influences and traditions, which have been reinterpreted, renegotiated, and integrated as key components to its complex identity.

\section{Reclaiming Identity by Redefining Womanhood}

There are several reasons for Chicana/o Studies' and particularly Chicana/o fiction's recent appeal on literary critics, scholars, and students, as well as its growing success with the general public - readers less familiar with the sociocultural background of the Chicana/o literary phenomenon, who nonetheless display an intense interest in it. But perhaps the simplest of all remains the basic psychological mechanism of identification: the mysterious, yet undeniably strong pull towards that which is considered 'alien,' strange, and exotic. In short, one might argue that the key element which draws the general public towards a kind of fiction which tackles intensely specific, thematically restrictive existential experiences is in fact the very enthrallment of alterity.

A few necessary comments must be made on the notion of identity and the central role it plays in defining the true nature of Chicana fiction before analyzing the process of identification and the manner in which readers of different ethnicities, coming from markedly dissimilar socioeconomic and cultural backgrounds, can relate to the experiences of Mexican American women of the barrio, for instance. As such, one must first and foremost establish the elements which, put together following a unique recipe of belonging and distinctiveness, constitute that specificity which makes the formation of identity possible. This recipe is of course complex and multifaceted, yet two are the essential, sine qua non components which make the end result hold and prevent it from disintegrating. These two components, ostensible as they may seem when looking at the word 'Chicana' for the first time, are as essential to correctly and fully grasping the literary phenomenon they define as they are obvious.

Indeed, what constitutes the identity foundation of Chicana fiction is the ethnicity and gender binary - quite unsurprisingly, Mexican Americanness and femininity are what stands at the core of an up-and-coming breed of literature written by women of bidirectional ethnic heritage. Ever since its inception, Chicana/o fiction has been 
marginalized by the promoters of the so-called 'high' culture, being often dismissed as less than, dispensable to the literary tradition, irrelevant to the large public - a public defined with the white, male, wealthy, and heterosexual model-reader in mind. As such, it was treated as an exotic, niche breed of literature at best and as non-literature at worst. Regardless of motive, the result of this 'center/margins' type of dichotomy has been, without exception, the exclusion of Chicana fiction from the literary canon altogether, in an attempt to delegitimize and discredit a kind of literature deeply rooted in a political and ideological struggle.

Thus, by denying Chicana fiction its place in the literary tradition and by deeming it aesthetically valueless, the patriarchal, center-oriented critical establishment hoped to render its extra-literary agenda silent and ultimately nip its aspirations in the bud. As seminal Chicana/o critic Francisco Lomelí puts it:

In essence, some considered it a bastard child since its contemporary manifestations were closely linked to barrio lifestyle, oral tradition and protest pamphleteerism along with conservable mythifications and, heaven forbid, a social conscience. Naysayers tended to emphasize its decentralized optics of possible subversion and an insistent heterodoxy in terms of thematics and world view. In fact, some even questioned if it was literature at all. ${ }^{4}$

Escaping categorization and voluntarily rejecting any type of restrictive classification and/or labeling, Chicana literature started defining itself by means of difference rather than similarity. As such, the Chicana group came into existence as a means of drawing attention to a niche within a niche, breaking away from the ideals and guidelines of the Chicano Movement by identifying itself as a reaction to a lacking system. There is contradiction and opposition at the very core of Chicana identity, stemming not just from the Chicana's complicated relationship with the world (namely the retrograde status quo, with academia serving as its most powerful bastion), but (perhaps especially) with herself.

Even inside their own ethnic cultural group, Chicanas felt underrepresented and, once again, 'alien.' To a certain extent, the very movement that was fighting to bring down patriarchalism as a worldview (i.e., idealizing the center and demonizing periphery as substandard) had managed to transform its female members into a historical footnote by ignoring them altogether. Since they felt betrayed by the Chicano Movement as a male-driven quest which did not deal with the status of women in its midst, Chicanas managed to forge their own identity as a reaction to this underrepresentation. Chicanas write in opposition to the symbolic representations of the Chicano movement that did not include them. Chicanas write

\footnotetext{
${ }^{4}$ The quoted excerpt is part of an article in progress by Francisco Lomelí, which he was kind enough to provide via an email exchange, while I was conducting research at the University of California, Santa Barbara.
} 
in opposition to a hegemonic feminist discourse that places gender as a variable separate from that of race and class. Chicanas write in opposition to academics, whether mainstream or postmodern, who have never fully recognized them as subjects, as active agents. However, defining themselves as women of hyphenated, thus hybrid identity (a mixture of Mexican descent and environmental exposure to the American society - be it called Mexican American, Chicana, mestiza or by any other name, depending on a number of variables and nuances) was not the end of the road for the Chicanas, but rather the beginning of a deeply refined and highly complicated quest for identity.

Resisting categorization, the one element that the Chicana identity group does exhibit as a common denominator is heterogeneity in all its forms and at various levels. Highly diverse in their individual self-definitions, ideological affiliation to one school of thought or another, socioeconomic class and personal ethnic histories, the members of the Chicana group never fail to make a strong political point. Thus, Chicana fiction, diverse and heterogeneous as it may be, is always sure to send a message that goes beyond mere aesthetic entertainment. It can even be argued that the 'art for art's sake' dictum might seem almost blasphemous when it comes to Chicana writers. Their writing is, without exception, packed with messianic intentions and underlying historical trauma. Their hybrid identity bleeds through the text and becomes the very soul of Chicana narrative.

Nothing is ever uncomplicated when it comes to this particular breed of literaturenot because it is intensely and vulgarly politicized/ideologized, but precisely because it is not. It is what lacks from the actual text, what remains unspoken and merely hinted at, that haunts the reader's conscience the longest. Once the seed of doubt (hidden in the very fabric of the text) hits the bountiful soil of an inquisitive mind (the reader's), meaningful questions arise. A sensitive reader cannot help but wonder how the formation of such tormented self-perception has been influenced by the socioeconomic context, by the transnational perspective, by gender disparities, by cultural marginalization, by lacking a sense of belonging.

It is fairly easy to conclude that all these elements are the very recipe that led to the forging of so unique a conglomerate that is contemporary Chicana identity. Having thus established that the Chicana consciousness is something extremely manifold and difficult to define, it becomes more and more obvious why a great majority of Chicana/o critics deem traditional, mainly European (and thus Eurocentric), centeroriented critical approaches unfit to use as valid theoretical tools in analyzing Chicana literature. Therefore, what many such critics emphasize is the necessity of rethinking theory in order to better accommodate this altogether new and perplexing type of literature that the Chicana/o identity group has produced. In the words of Chicana feminist Norma Alarcón, 
La perspectiva crítica sólo surge claramente cuando no existe una tradición que recoja nuestra propia actitud y cuando uno se da cuenta de que se enfrenta a una tradición extraña a la que nunca ha pertenecido o a la que ya no acepta sin cuestionar. ... Las principales actitudes literarias chicanas, tanto de hombres como de mujeres, se reúnen en torno a la búsqueda de la autodeterminación, la autodefinición, junto con un proceso de autoinvención en los intersticios de varias culturas. ${ }^{5}$ (Alarcón, 1990: 208)

The Chicana literary universe is inhabited by themes and topics as diverse as they are compelling and provocative. Characters and situations are never unilateral, artificial, pretentious or untrue to the authors' own personal backgrounds and identity struggles. Without resorting to magical realism as a defining genre, Chicana novels are often occupied by a type of hidden, impossible-to-pinpoint magical substrate. A somewhat mysterious identity group, the Chicanas/os have always been a source of fascination and puzzlement for outsiders, for those who did not share their hybrid spirit and intricate genealogy.

\section{The Border, an Ambivalent Metaphor}

Symbolic inhabitants of Aztlán, their mythical and mystical (half real, half imaginary) Aztec homeland, the Chicanas/os belong to the physical world only partially, insomuch as their borderless ancestry allows them to. Part Mexican American, part heirs to a mysterious native land that they only inhabit fictionally and at an oneiric level, Chicanas/os manage to both fascinate and perplex outsiders. Whether this acknowledgement of otherness manifests itself positively (as fascination and idealization) or negatively (as repulsion or fear), the inadequateness of the approach remains: the Chicana/o is either exoticized or demonized; either way, objective and knowledgeable assessment eludes the outsider completely.

This is where Chicana/o fiction comes in: by way of narrative discourse, it aims at clearing up some essential aspects regarding Chicana/o identity. Writing and reading prove cathartic acts for both author and reader, as the fictional world often becomes the window into a reality far more accurate and poignant than any sociological or anthropological account. Returning to the mythical space of Aztlán, it is partly curious, partly understandable and psychoanalytically explainable that the lead figure of Chicana feminism, writer Gloria Anzaldúa, rejects this spatial

\footnotetext{
5 "The critical perspective only emerges clearly when there is no tradition that picks up our own attitude and when one realizes that they are facing a strange tradition to which they had never belonged or that they no longer accept without question. ... The main Chicana literary attitudes of both men and women center on the search for self-determination, selfdefinition, along with a process of self-invention in the interstices of various cultures." Translation mine.
} 
representation of redemption and belonging as a predominantly male construct, a safe haven that excludes women by omission. For the Chicanas, the revolt against colonization does not stop at an ethnic and cultural level; their struggle continues to brew inside the very Chicana/o identity group that they belong to, both racially and culturally. Anzaldúa proposes replacing this space, built according to male notions of nationalism, with the 'Coatlicue State' — an empowering, highly feminized concept of geography. According to Norma Khlan, this 'Coatlicue State' can be read as the very point of origin of a renewed identity:

An empowering myth, it re-turns to the origins, inscribing a fe-male re-membering of the community intent on retrieving a cultural sense of self erased through colonization. ... From this plurilingual, multicultural space built by the layering of histories of conquest, imperialism, and diaspora, a "new mestiza consciousness" is born, one that contests the patriarchal hierarchies deeply entrenched in the imagined community. (Khlan, 2003: 121)

Chicanas experience marginalization as the painfully predictable and equally inevitable result of the politics of xenophobia and homophobia that have long characterized the Eurocentric male-centered canon. In order to escape it, what Chicanas need most is a shift in perspective - not just as far as criticism is concerned, but especially in terms of self-perception. The colonization of the mind, first theorized by Frantz Fanon in his most influential work, Black Skin, White Masks is the one obstacle that prevents Chicana identity from truly taking literary and conceptual form.

The line between literature and reality is blurred, which is why a number of Chicana writers, from Sandra Cisneros to Stella Pope Duarte, use autobiographical fiction as a means of exorcizing personal demons and reasserting their own hybrid identities. Regardless of literary form or structure, the message that transcends the text is often one and the same: discovering and reclaiming oneself is only possible once awareness enters the picture - ethnic awareness, gender awareness, self-awareness. Therefore, it is by no means surprising that many Chicana novels depict coming-ofage stories, being narratively organized in the form of a Bildungsroman, with The House on Mango Street (1985) by Sandra Cisneros, The Last of the Menu Girls (1986) by Denise Chávez, and So Far from God (1993) by Ana Castillo among the most famous.

Having been part of a widely traditional, patriarchal culture for so long, Chicanas feel invisible and traumatized, victims of unspeakable abuse deemed 'normal' only because it had been ritualistically repeated until entering the mainstream of everyday practice. By daring to finally utter and therefore expose all that had been left unsaid throughout the lifelong experience of being a Chicana, this particular type of Bildungsroman becomes - as Annie O. Eysturoy argues in her book Daughters of Self-Creation - a "subversive act" in itself (Eysturoy, 1996: 85). 
Unable to accept ethnic belonging as the only definitive reason for discrimination, the Chicanas form a subgroup within their own larger Chicana/o identity conglomerate, throwing gender in the mix as an indispensable element for a valid definition of their very essence.

Recalling Gayatri Spivak's famous text "Can the Subaltern Speak?," one cannot help but wonder at what point the "new mestiza consciousness" theorized by Gloria Anzaldúa actually emerged and which exactly was the decisive force that triggered it, causing it to take shape and enter the realm of the written text as a powerful literary manifesto. It becomes quite obvious that the Chicanas felt oppressed within the very group that was supposed to represent them and hold their best interests at heart. They were the subaltern (by adding the second layer of difference through gender) in a group already comprised of subalterns (in terms of ethnicity and racial/cultural dissimilarities), thus a subsection twice traumatized by the burden of invisibility and voicelessness: firstly by being Chicanas and secondly by being women. Sometimes additional elements are also part of the marginalization recipe: many of these women are part of the lower classes (so the sociopolitical aspects cannot be ignored) and/or belong to a sexual minority, as well, since Gloria Anzaldúa's lesbianism has always been considered (by herself, declaratively, and by central Chicana/o critics) a key element of her writing and an important component of her identity.

\section{Chicana Identity and the Ideology Behind La Lucha}

Being situated at the bottom of the abuse ladder, so to speak, or at the end of the trophic chain in terms of power can often result in despair and defeat. Not so for the Chicanas, who end up using the power of the oppressive environment and reluctant canon as a backfiring weapon. Embracing difference, putting everything in writing, taking over the text, giving a voice to the voiceless through fiction becomes the very object of Chicana redemption. In short, it all becomes a tool of empowerment in the long run. An entirely new and interesting form of group identity is thus forged, going through all the stages that Ellen McCracken deems as essential in the "gendered construction of ethnic identity":

Group identity is forged both through internal shared experience and oppositionality to the Other. In its positive moments, it is affirmational, contestatory, and begins to achieve social reform. In its negative stages, however, it is exclusionary, individualist, and essentialist. ... Many of these narratives strive for a dual oppositionality and often constitute a doubly subordinated culture. (McCracken, 1999: 179)

Instead of being embraced and cherished, difference is often portrayed as a tumor that must be excised and never allowed to grow back again. Even the fact that the Chicana is supposed to define herself in opposition to her male counterpart is 
demeaning and highly restrictive in itself. Chicana writers that propose the discussion of female identity and individual women's destinies in their works are painfully aware of the fact that these women's own sense of self has been altered as a result of majority rule. In Sandra Cisneros' The House of Mango Street, poverty as yet another form of marginalization (this time social) becomes a central element to Chicanas' oppression and voicelessness. It is the lack of money that makes Chicanas dependent on men, therefore reasserting male dominance and the women's status as inferior, second-rate citizens.

Actual violence (physical and sexual) is merely the way in which psychological dependence penetrates tangible reality. Among the most raw and dramatic accounts is that of Esperanza's rape, since it speaks volumes on the role that the Chicana is allowed in the confined society that men have designed for her: "He wouldn't let me go. He said, I love you, I love you, Spanish girl” (Cisneros, 1991: 94). The Chicana is thus reduced to playing the part of the exoticized sexual object, without thoughts or feelings of her own-a soulless doll of Latin descent, meant to fleetingly fulfil male urges and then be discarded without a word. Interestingly enough, however, even if brute force is exercised by male actors, it appears that the moral authors of abuse are many times women in the community - friends, sisters, mothers - , who tell little girls idealized stories of love and what sexuality is really about: "They all lied. All the books and magazines, everything that told it wrong" (Cisneros, 1991: 94), obscuring the dangers and violence that male-centric society has in store for them. By observing all the female characters on Mango Street in search of a personal role model, Cisneros' Esperanza manages to hold up a mirror and put together a disturbing portrait of the Chicana as a victim, the way she is revealed in relation to men and to a money-oriented society that has her marginalized, disenfranchised, and condemned to male dependence. The house, a protective space of refuge, which is supposed to reflect the very identity of the inhabitant and offer shelter in the face of adversity, replenishing one's energies, is a place of torment and imprisonment for fictional Chicanas - the same way that it proves stifling and destructive to their reallife counterparts.

Through her rebellion and refusal to comply to restrictive societal norms-breaking the cycle of dependence and hence self-victimization-, Esperanza offers hope (much like her name had suggested from the very beginning) to the entire Chicana group. When she understands that breaking free means accepting, embracing, and cherishing one's inherent difference as a source of empowerment, Esperanza offers the key to comprehending Chicana identity altogether. Not belonging with the mainstream, swimming against the current, gathering the courage to stand out from the submissive crowd are all steps towards the ultimate quest of finding oneself: "I like to tell stories. I am going to tell you a story about a girl who didn't want to belong" (Cisneros, 1991: 101). 


\section{Conclusion}

Slaves to a preordained trajectory of their existence, Chicana characters are often fictional echoes of real-life women whose destinies are in dire need of a literary voice. The 'virgin/whore' dichotomy is often cited as quintessential to female identity even today, to the despair of Chicanas who wish to escape such a simplistic and reductionist perspective. Torn between ancestral female models such as the Virgin of Guadalupe and the La Malinche/La Llorona mix, Chicanas are not offered the 'luxury' of having a personality of their own choosing, one to provide an accurate and complex enough portrayal of who they really are. What is all the more disturbing and destructive is not that such views are forced on Chicanas from the outside, but that the same pattern of assessment is embraced and unconsciously applied even when it comes to self-perception and self-definition - such is the damage inflicted by the colonization of the mind to which these women had been subjected. For many of them who represent the 'margins' and are yet to break free from the centuries-old oppressive framework inflicted by the so-called 'center,' the way to building an authentic identity requires an existence free from patriarchal biases and traumatizing pigeonholing, through a genuine renewal of their own sense of self.

\section{References and bibliography}

Alarcón, N. 1990. "La literatura chicana: un reto sexual y racial del proletariado," in López González A. et al. (eds.), Mujer y literatura mexicana y chicana: Culturas en contacto, vol. 2., Tijuana: El Colegio de México/El Colegio de la Frontera Norte: 207-212.

Anzaldúa, G. E. 1987. Borderlands/La Frontera: The New Mestiza, San Francisco: Aunt Lute Books.

Appiah, K. A. 2005. The Ethics of Identity, Princeton: Princeton University Press.

Assmann, J. 2006. Religion and Cultural Memory: Ten Studies, Stanford: Stanford University Press.

Bakhtin, M. M. and M. Holquist. 1981. The Dialogic Imagination: Four Essays, Austin: University of Texas Press.

Cisneros, S. 1991. The House on Mango Street, New York: Vintage Contemporaries.

Clifford, J. 1997. Routes: Travel and Translation in the Late Twentieth Century, Cambridge, MA: Harvard University Press.

Eysturoy, A. O. 1996. Daughters of Self-Creation. The Contemporary Chicana Novel, Albuquerque: University of New Mexico Press.

Fanon, F. 2008. Black Skin, White Masks, New York: Grove Press; Berkeley: Publishers Group West.

Khlan, N. 2003. "Literary (Re)Mappings: Autobiographical (Dis)Placements by Chicana Writers," in Arredondo G. F. et al. (eds.), Chicana Feminisms: A Critical Reader, Durham: Duke University Press: 114-145. 
Lomelí, F. A. 2012. The Chican@Literary Imagination: A Collection of Critical Studies, Canero J. and J. F. Elices (eds.), Madrid: Universidad de Alcalá.

McCracken, E. 1999. New Latina Narrative: The Feminine Space of Postmodern Ethnicity, Tucson: The University of Arizona Press.

Spivak, G. C. 1988. "Can the Subaltern Speak?," in Nelson C. and L. Grossberg (eds.), Marxism and the Interpretation of Culture, Urbana: University of Illinois Press: 66-111.

\section{The author}

Dr. Monica Got is a lecturer with the Department of Modern Languages and Business Communication at the Bucharest University of Economic Studies, where she teaches Business Communication in English. In 2014-2015, she was a junior Fulbright scholar to the U.S. with the Chicano/a Studies Department at the University of California, Santa Barbara. She holds a doctoral degree in Literary and Cultural Studies from the University of Bucharest, with a dissertation titled "Crossing Borders, Merging Homelands. Traumatic Identities in Contemporary Chicana Fiction." Her experience abroad includes a master's program in Paris at the Universite Paris Est-Créteil and a school year teaching English in Catalonia, with a European Commission-funded project. Dr. Got delivered talks at international conferences and published extensively on such issues as hybrid identity, cultural trauma, transnationalism, acculturation, border theory, and collective memory. 